\title{
Mild cognitive impairment and progression to dementia of Alzheimer's disease
}

\author{
Ana Beatriz Quintes Steiner ${ }^{1 *}$, Alessandro Ferrari Jacinto², Vânia Ferreira de Sá Mayoral ${ }^{3}$, Sonia Maria Dozzi Brucki", \\ Vanessa de Albuquerque Citero 5 \\ ${ }^{1}$ MD, Psychiatrist, Psychogeriatrist, MSc Student, Psychiatry Department, Escola Paulista de Medicina (EPM), Universidade Federal de São Paulo (Unifesp), São Paulo, SP, Brazil \\ ${ }^{2} \mathrm{MD}$, PhD, Geriatrist, Assistant Professor of Geriatrics, Department of Internal Medicine, Faculdade de Medicina de Botucatu (FMB), Universidade Estadual Paulista Júlio de Mesquita Filho (Unesp), Botucatu, SP, Brazil \\ ${ }^{3} \mathrm{MD}$, Geriatrist, MSc in Collective Health, FMB-Unesp, Botucatu, SP, Brazil \\ ${ }^{4} \mathrm{MD}$, Neurologist. MSc and PhD in Neurology, Unifesp. Post-Doctoral degree from Universidade de São Paulo (USP). Preceptor of the Neurology Residency Program at Hospital Santa Marcelina. Assisting Physician \\ of the Grupo de Neurologia Cognitiva e do Comportamento e do Centro de Referência em Distúrbios Cognitivos (Ceredic), USP, São Paulo, SP, Brazil \\ ${ }^{5} \mathrm{MD}$, Psychiatrist, Associate Professor of the Psychiatry Department, EPM-Unifesp, São Paulo, SP, Brazil
}

Study conducted at the Psychiatry Department, Escola Paulista de Medicina, Universidade Federal de São Paulo, São Paulo, SP, Brazil

Article received: $1 / 15 / 2017$ Accepted for publication: $2 / 5 / 2017$ *Correspondence: Address: Rua Borges Lagoa, 570 São Paulo, SP - Brazil Postal code: 04038-030 drabsteiner@yahoo.com.br

\section{SUMmARY}

The increase in life expectancy in the Brazilian population raises questions about the preparation of the public health system in identifying elderly patients with signs of cognitive impairment. Currently, as a consequence of the long duration of preclinical phase of Alzheimer's disease, efforts of early detection have been emphasized. Clinical dementia presents an important impact on the individual's caregivers, family, society and economy. Identifying individuals who already have some cognitive impairment, despite remaining functional, as well as analyzing associated comorbidities, constitutes an opportunity to analyze possibilities for future interventions. Dementias are clinical conditions that impose a burden on the health system with its high costs, whereas the identification of individuals with cognitive impairment without dementia can aid patients and their families to plan the future and mitigate costs. This narrative revision can provide general practitioners with more information on the subject.

Keywords: elderly, cognitive deficits, mild cognitive impairment, general practice, Alzheimer's disease, diagnosis.

\section{INTRODUCTION}

In the last decades, Brazil has undergone rapid demographic transition with an increase in the population of elderly. The Brazilian life expectancy has reached 73 years and, currently, the elderly represent approximately $10 \%$ of the general population. In 2030, they will be $36 \%{ }^{1,2}$

Along with the aging of the global population, there is an increase in the incidence and prevalence of diseases associated with senility including mild cognitive impairment (MCI) or, according to DSM-5, mild neurocognitive disorder. ${ }^{3}$ Subjects aged 60 years or older with subjective cognitive complaints corroborated by an informant show an increased conversion rate to MCI or to dementia. ${ }^{4}$ The risk of elderly individuals with subjective cognitive complaints to progress to MCI or dementia is 1.5 to 3 higher than in those without it. ${ }^{5}$ According to Petersen et al. ${ }^{6}$ the annual conversion rate of amnestic-type MCI to clinical dementia ranges from 10 to $15 \%$.
The term "mild cognitive impairment" was first suggested in 1980 by Reisberg et al.7 The first paper on MCI was published in 1994 by Petersen; ${ }^{8}$ but only in 1999 Petersen et al. ${ }^{6}$ further developed the concept by proposing criteria based on an observational study on ageing. The concept of MCI defines an early but abnormal stage of cognitive harm, no longer considered a normal part of aging, and therefore a diagnostic entity and pathological condition. The initial criteria were: a) subjective impairment of the memory, preferentially confirmed by an informant; b) objective impairment of the memory compared with a group paired by age and education level (below 1.5 standard deviations from the mean); c) normal global cognitive functioning; d) independence in daily life activities; and e) absence of dementia. This concept is based on the observation that Alzheimer's disease $(\mathrm{AD})$ progresses insidiously, usually initiating with a memory deficit that is well characterized, and may allow the diagnosis of $\mathrm{AD}$ in the phase of pre-dementia. ${ }^{9}$ 
At a Key Symposium held in Stockholm in the year 2003, MCI was defined as a heterogeneous entity divided into three categories: amnestic MCI with greater risk of $\mathrm{AD}$; $\mathrm{MCI}$ of multiple cognitive domains; and MCI with impairment of a single cognitive function different from memory. ${ }^{10}$ Main diagnostic points of MCI were redefined: the individual being neither normal nor demented; evidence of cognitive decline measured objectively or based on subjective perception combined with objective cognitive impairment; preservation of basic living and complex instrumental activities or minimally compromised.${ }^{10} \mathrm{~A}$ task force of American authorities, led by the National Institute of Aging and the Alzheimer's Association, proposed a review of the criteria used for the classification of MCI in 2011. ${ }^{11}$ Despite the basic clinical criteria being similar to those for MCI diagnosis, this review opened the focus on the probable etiological mechanisms that lead to cognitive impairment, with emphasis on early diagnosis of $\mathrm{AD}$, via the utilization of biomarkers.

The term "mild cognitive disorder" was included in the International Classification of Diseases (ICD) to be applied to patients that presented a decline in cognitive performance, usually accompanied by abnormalities in objective tests for cognitive functions, but not sufficiently to fulfill the diagnostic criteria of dementia. ${ }^{12}$

\section{EPIDEMIOLOGY}

The first population-based study on the prevalence of MCI and its subtypes (Figure 1$)^{13}$ was based on a cardiovascular health study. ${ }^{14}$ The researchers applied the criteria for MCI retrospectively in a cohort and found a prevalence of $22 \%$, of which $6 \%$ referred to the amnestic subtype and $16 \%$ to multiple domains in patients aged 65 years or older. ${ }^{15}$ Other studies demonstrated an incidence rate from 1 to $6 \%$ per year and a prevalence of 3 to $22 \%{ }^{15}$ The prevalence and incidence of MCI found in Brazil was similar to rates observed in other countries. ${ }^{16}$ In a riverside-dwelling population with low education and practically no vascular risk factors, MCI prevalence was $7.7 \% .{ }^{17}$ A systematic review and meta-analysis on the prevalence of dementia among individuals aged 60 years or older found a narrow range of 5-7\% in most world regions, with a higher prevalence in Latin America (8.5\%), and a distinctively lower prevalence in the four sub-Saharan African regions (2-4\%). ${ }^{18}$ In this study, 35.6 million people lived with dementia worldwide in 2010, with numbers expected to almost double every 20 years, to 65.7 million in 2030 and 115.4 million in 2050. Yet, in 2010, $58 \%$ of all people with dementia lived in countries with low or middle incomes, with this proportion expected to rise to $63 \%$ in 2030 and $71 \%$ in $2050 .{ }^{18}$

\section{Progression to AD (Figure 2) ${ }^{\mathbf{1 9}}$}

Several authors observed an increased rate of progression toward dementia in patients with MCI. ${ }^{8,20-25}$ However, studies have not been replicated by other researchers. One explanation for this fact may arise from the observation that memory complaints appear to have little correlation with the performance of individuals on objective cognitive tests. ${ }^{26}$

On the other hand, longitudinal studies revealed that elderly individuals with recent complaints of impaired memory performed worse in memory tests than those who had not had such a complaint in one year of follow-up. They suggest that memory complaints from the elderly must be taken even more seriously when accompanied by objective signals of cognitive deterioration..$^{27,28}$ Despite some discrepancies among studies, the researchers agree that individuals diagnosed with MCI develop dementia at a faster rate than the rest of the population.

\section{Evaluation OF MEMORY PROBLEMS}

The initial evaluation must rely on careful obtainment of patient history and of memory complaint, always comparing to previous functional state of cognitive complaint, ${ }^{29}$ establishing a chronology for the initiation of symptoms, as well as habits and comorbidities; investigation of mood symptoms and behavioral alterations. Questions on dietary and sleep habits must be posed. ${ }^{30,31}$ Detailed neurological and general physical exam must be carried out, with thorough observation of gait and verification of motor signals (alterations of reflexes, rigidity, bradykinesia, tremor, slowness). ${ }^{32}$ The laboratory exams that must be performed to rule out reversible dementia syndromes include:

- Thyroid hormone tests to investigate underactive thyroid.

- Vitamin B12 blood test to check vitamin deficiency.

- Complete blood count to investigate infections.

- Aspartate aminotransferase (AST) and alanine aminotransferase (ALT) blood tests that check liver function.

- Chemistry screening to check the level of electrolytes in the blood and to check kidney function.

- Glucose test to check the level of sugar in the blood.

- VDRL and HIV.

- Erythrocyte sedimentation rate, a blood test that investigates signs of inflammation in the body.

- Toxicology screening, examining blood and urine.

- Antinuclear antibodies, a blood test used to diagnose autoimmune diseases.

- Investigation of heavy metals in the blood, such as a lead test. ${ }^{33}$

- A lumbar puncture to test for certain proteins in the spinal fluid. 


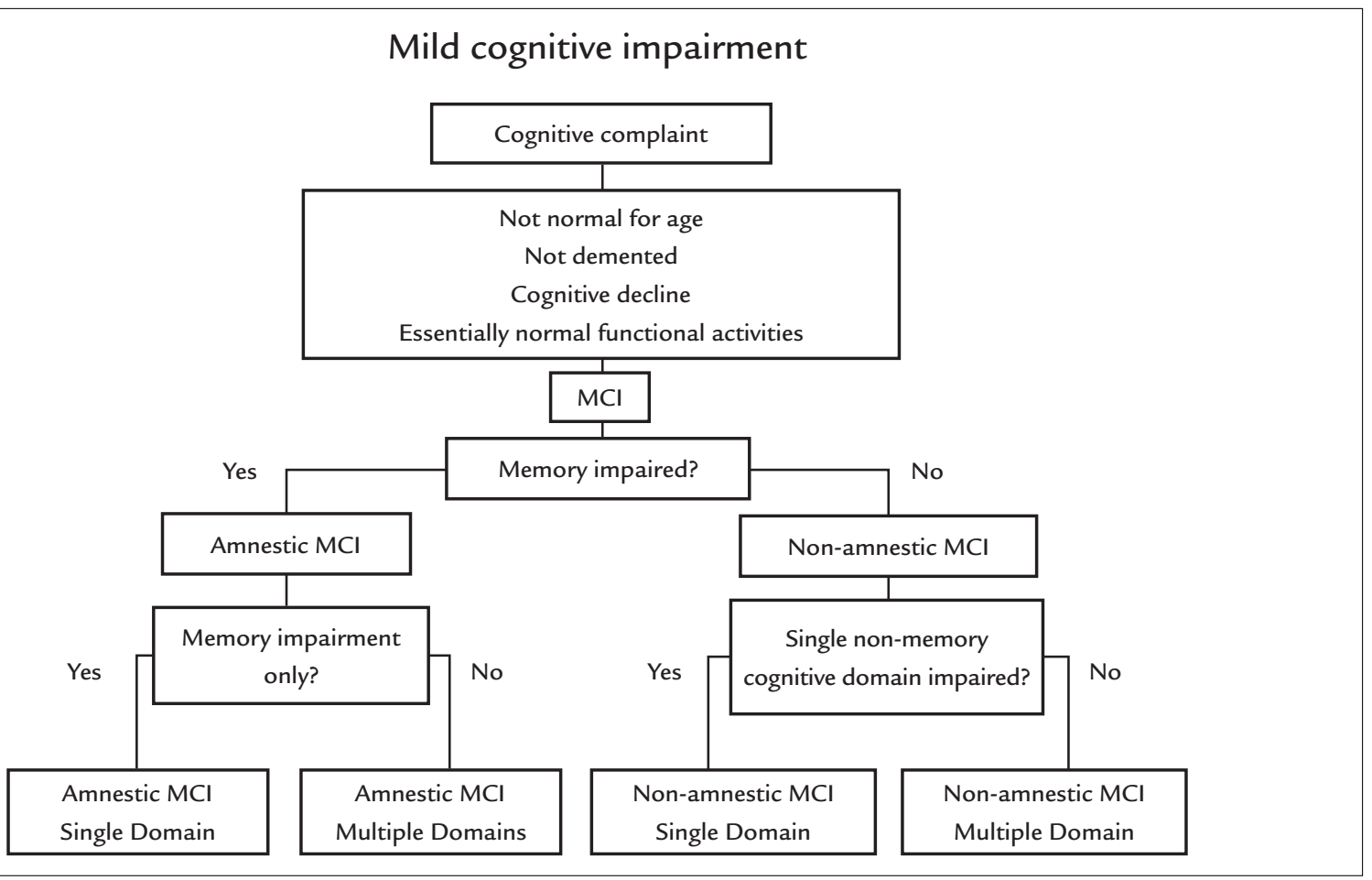

FIGURE 1 Current algorithm used to classify the subtypes of mild cognitive impairment (MCI).

Source: Petersen R. ${ }^{13}$

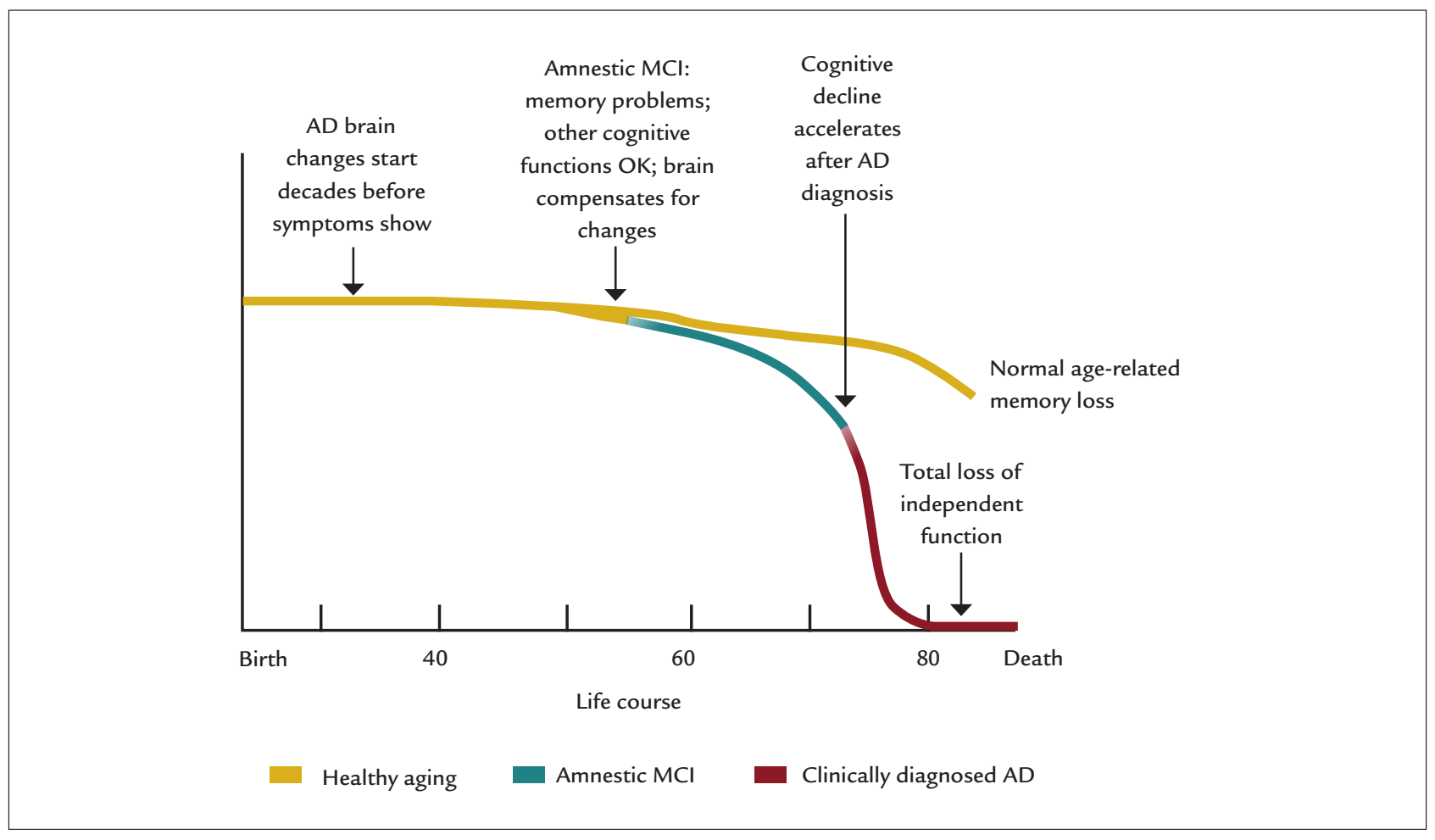

FIGURE 2 Charting the Course from Healthy Ageing to AD.

$\mathrm{MCl}$ : mild cognitive impairment; AD: Alzheimer's disease.

Source: National Institute On Aging - NIH. 
Neuroimaging exams must be requested, including CT or MRI scans, not only to verify the limbic structures but also to rule out other diseases, particularly vascular cognitive impairment. ${ }^{34}$

Screening tests such as the mini-exam of the mental state, ${ }^{35}$ clock-drawing test, verbal fluency and a questionnaire on instrumental and basic daily life activities, as well as the geriatric depression scale (GDS) questionnaire, must be applied. ${ }^{36,37}$

\section{NeUropsychological testing}

Longitudinal studies investigating the usefulness of neuropsychological tests to identify subjects at high risk of developing dementia reported that, by measuring recall, delayed recall, verbal fluency and visual-motor skill, they were able to identify $85 \%$ of the individuals that developed dementia and $95 \%$ of those that remained stable, in four years of accompaniment. ${ }^{23}$ The results suggest that individuals with increased risk of developing dementia, or in a preclinical state of $\mathrm{AD}$, can be identified by neuropsychological tests, which evaluate mainly memory (measures of late evocation) and other cognitive functions, such as attention, language and thought. ${ }^{23}$ The standardized application of tests to elderly individuals with cognitive complaints is a manner of rendering the concept of cognitive impairment both valid and reliable..$^{38}$

\section{Neuroimaging}

In the initial stages of the disease, cranial MRI might not present abnormalities. In some cases, a SPECT or PET scan can be considered. ${ }^{30}$ In SPECT a decline in blood flow is noted whereas in PET a reduction of glucose utilization is observed. PIB and FDG PET are employed in some research studies to compare controls with patients suffering from $\mathrm{AD}$ and MCI. ${ }^{39}$

\section{Treatment}

Currently, there is no evidence for the utilization of drugs for the treatment of individuals with $\mathrm{MCI} .{ }^{40}$ Nonetheless, several clinical trials have been conducted in an attempt to slow down the appearance of dementia. ${ }^{41}$ There was a large clinical trial involving 70 medical centers in North America. ${ }^{42}$ The study was randomized, double-blind and placebo-controlled and aimed to verify the safety and efficacy of vitamin E (2,000 IU per day) and donepezil (10 $\mathrm{mg}$ per day). A decrease, although not significant, was noted in the conversion rate of MCI to AD from 45 to $30 \%$ in a three-year period. Among 769 randomized individuals, the annual conversion rate of $\mathrm{MCI}$ to $\mathrm{AD}$ was approximately $16 \%$. Donepezil reduced the risk of AD in the first 12 months of the trial, but there was no drop in the progression to AD in 36 months. Vitamin E had no therapeutic effect. ${ }^{43}$

\section{Conclusion}

Aging of the population is making the cases of chronic degenerative diseases more frequent, including $\mathrm{AD}$. In MCI, a loss of memory for recent facts with relative preservation of functionality is observed. A general practitioner must know that individuals with $\mathrm{MCI}$ constitute a group of great risk for AD. Early identification of individuals in the beginning of clinical dementia provides a possibility of intervening in the progression of the disease and providing support to patients and their family members. Upon encountering elderly patients with memory complaints, the physician must perform a detailed anamnesis and complete physical exam, ruling out reversible causes of cognitive alterations. Mood symptoms such as depression and anxiety, if identified, need to be treated. Laboratory exams must include a complete blood count, fasting blood glucose, electrolytes, renal, liver and thyroidal function, lipidogram, folic acid and vitamin B12. An imaging exam such as cranial CT or MR should also be performed. Cognitive testing must include a mini-exam of the mental state (mini-mental), clock-drawing test and verbal fluency for fruits and animals. The Brazilian Public Health System (SUS, in the Portuguese acronym) is responsible for a great portion of patient healthcare in the country. The Family Health Team of Basic Health Units must serve as both the first contact and the longitudinal contact with SUS users, enabling the recognition of the patients' cognitive impairment and potential progression to $\mathrm{AD}$.

\section{Resumo}

Comprometimento cognitivo leve e progressão para a demência da doença de Alzheimer

O aumento da expectativa de vida da população brasileira faz surgir questões sobre o preparo do sistema de saúde pública na identificação de pacientes idosos com sinais de alteração cognitiva. Atualmente, como consequência da longa duração da fase pré-clínica da doença de Alzheimer (DA), existe maior ênfase sobre a detecção precoce. A demência apresenta um importante impacto sobre a família, os cuidadores, a sociedade e a economia. Identificar indivíduos que já apresentam algum comprometimento cognitivo, embora eles mantenham a funcionalidade, bem como analisar as comorbidades associadas constituem oportunidades para direcionar futuras intervenções. Demências são doenças que impõem sobrecarga ao sistema 
público de saúde, com altos custos. A identificação de indivíduos com alteração cognitiva sem demência pode adicionar planejamentos futuros por parte do próprio doente, da sua família e dos cuidadores, resultando em menor sobrecarga física e emocional para todos os envolvidos. Esta revisão narrativa tem como objetivo ajudar os clínicos gerais a atuar na detecção dos idosos que se encontram em risco de desenvolver demência.

Palavras-chave: idoso, déficit cognitivo, comprometimento cognitivo leve, clínico geral, doença de Alzheimer, diagnóstico.

\section{RefEREnCES}

1. SPDM. A Saúde do Brasil em 2021 Reflexões sobre os desafios da próxima década. 2012 [cited 2016 Sep 22]. Available from: http://www.sindhosp.com. br/anexos/saude_brasil.pdf.

2. IBGE. Brasil: uma visão geográfica e ambiental do inicio do século. In: Brasil: uma visão geográfica e ambiental do inicio do século [Internet]. Instituto Brasileiro de Geografia e Estatística; 2016 [cited 2016 Sep 22]. Available from: http://www.ibge.gov.br/home/.

3. Araújo AC, Lotufo Neto F. A nova classificação americana para os transtornos mentais: o DSM-5. Rev Bras Ter Comport Cogn [online]. 2014; 16(1):67-82.

4. Studart Neto A, Nitrini R. Subjective cognitive decline: the first clinical manifestation of Alzheimer's disease? Dement Neuropsychol. 2016; 10(3):170-7.

5. Mendonça MD, Alves L, Bugalho P. From subjective cognitive complaints to dementia: who is at risk? A systematic review. Am J Alzheimers Dis Other Demen. 2016; 31(2):105-14.

6. Petersen RC, Doody R, Kurz A, Mohs RC, Morris JC, Rabins PV, et al. Current concepts in mild cognitive impairment. Arch Neurol. 2001; 58(12):1985-92.

7. Reisberg B, Ferris SH, de Leon MJ, Crook T. The Global Deterioration Scale for assessment of primary degenerative dementia. Am J Psychiatry. 1982; 139(9):1136-9.

8. Petersen RC, Caracciolo B, Brayne C, Gauthier S, Jelic V, Fratiglioni L. Mild cognitive impairment: a concept in evolution. J Intern Med. 2014; 275(3):214-28.

9. Forlenza OV, Diniz BS, Gattaz WF. Diagnosis and biomarkers of predementia in Alzheimer's disease. BMC Med. 2010; 8:89.

10. Winblad B, Palmer K, Kivipelto M, Jelic V, Fratiglioni L, Wahlund L-O, et al. Mild cognitive impairment--beyond controversies, towards a consensus: report of the International Working Group on Mild Cognitive Impairment. J Intern Med. 2004; 256(3):240-6.

11. Sperling RA, Aisen PS, Beckett LA, Bennett DA, Craft S, Fagan AM, et al. Toward defining the preclinical stages of Alzheimer's disease: recommendations from the National Institute on Aging-Alzheimer's Association workgroups on diagnostic guidelines for Alzheimer's disease. Alzheimers Dement. 2011; 7(3):280-92

12. Zanuto E. Demência e transtornos cognitivos em idosos. Rev Bras Psiquiatr. 2006; 28(4):344-344.

13. Petersen, R. Early diagnosis of Alzheimer's disease: is MCI too late? Current Alzheimer Research. 2009; 6(4):324-30.

14. Fried LP, Borhani NO, Enright P, Furberg CD, Gardin JM, Kronmal RA, et al. The Cardiovascular Health Study: design and rationale. Ann Epidemiol. 1991; 1(3):263-76

15. Lopez OL, Jagust WJ, DeKosky ST, Becker JT, Fitzpatrick A, Dulberg C, et al. Prevalence and classification of mild cognitive impairment in the Cardiovascular Health Study Cognition Study: part 1. Arch Neurol. 2003; 60(10):1385-9.

16. Bennett DA, Wilson RS, Schneider JA, Evans DA, Beckett LA, Aggarwal NT, et al. Natural history of mild cognitive impairment in older persons. Neurology. 2002; 59(2):198-205.

17. Brucki SMD. Epidemiology of Mild Cognitive Impairment in Brazil. Dement Neuropsychol. 2013; 7(4):363-6.

18. Prince M, Bryce R, Albanese E, Wimo A, Ribeiro W, Ferri CP. The global prevalence of dementia: a systematic review and metaanalysis. Alzheimers Dement. 2013; 9(1):63-75.e2.
19. Rodgers AB. Alzheimer's disease: unraveling the mystery. US Department of Health and Human Services. NIH Publication Number 08-3782. September 2008

20. Stein DJ, Kupfer DJ, Schatzberg AF, American Psychiatric Publishing, organizers. The American Psychiatric Publishing textbook of mood disorders. Washington, DC: American Psychiatric Pub; 2005. 778 p.

21. Gertz H-J, Arendt T. Alzheimer's disease: from basic research to clinical applications [Internet]. Wien; New York: Springer; 1998 [cited 2016 Sep 22]. Available from: http://public.eblib.com/choice/publicfullrecord. aspx?p=3099145.

22. Weintraub S, Wicklund AH, Salmon DP. The neuropsychological profile of Alzheimer disease. Cold Spring Harb Perspect Med. 2012; 2(4):a006171.

23. Chaves ML, Godinho CC, Porto CS, Mansur L, Carthery-Goulart MT, Yassuda MS, et al. Doença de Alzheimer. Avaliação cognitiva, comportamental e funcional. Dement Neuropsychol. 2011; 5(Suppl 1):21-33.

24. Crowe M, Andel R, Wadley V, Cook S, Unverzagt F, Marsiske M, et al. Subjective cognitive function and decline among older adults with psychometrically defined amnestic MCI. Int J Geriatr Psychiatry. 2006; 21(12):1187-92.

25. Petersen RC, Smith GE, Waring SC, Ivnik RJ, Tangalos EG, Kokmen E. Mild cognitive impairment: clinical characterization and outcome. Arch Neurol. 1999; 56(3):303-8.

26. Bottino CMC, Laks J, Blay SL. Demência e transtornos cognitivos em idosos. Rio de Janeiro: Guanabara Koogan; 2006. 472 p.

27. Schmand B, Jonker C, Hooijer C, Lindeboom J. Subjective memory complaints may announce dementia. Neurology. 1996; 46(1):121-5.

28. Schofield PW, Logroscino G, Andrews HF, Albert S, Stern Y. An association between head circumference and Alzheimer's disease in a population-based study of aging and dementia. Neurology. 1997; 49(1):30-7.

29. Amoruso L, Ibáñez A, Fonseca B, Gadea S, Sedeño L, Sigman M, et al. Variability in functional brain networks predicts expertise during action observation. NeuroImage. 2017; 146:690-700.

30. Frota NAF, Nitrini R, Damasceno BP, Forlenza O, Dias-Tosta E, Silva AB, et al. Critérios para o diagnóstico de doença de Alzheimer. Dement Neuropsychol. 2011; 5(Suppl 1):5-10.

31. Sindi S, Mangialasche F, Kivipelto M. Advances in the prevention of Alzheimer's disease. F1000Prime Rep. 2015; 7:50.

32. Mattos P, Lino V, Rizo L, Alfano Â, Araújo C, Raggio R. Memory complaints and test performance in healthy elderly persons. Arq Neuropsiquiatr. 2003; 61(4):920-4.

33. Chi GC, Fitzpatrick AL, Sharma M, Jenny NS, Lopez OL, DeKosky ST. Inflammatory biomarkers predict domain-specific cognitive decline in older adults. J Gerontol A Biol Sci Med Sci. 2017; 72(6):796-803

34. Damasceno BP. Neuroimaging in normal pressure hydrocephalus. Dement Neuropsychol. 2015; 9(4):350-5.

35. Brucki SMD, Nitrini R, Caramelli P, Bertolucci PHF, Okamoto IH. [Suggestions for utilization of the mini-mental state examination in Brazil]. Arq Neuropsiquiatr. 2003; 61(3B):777-81.

36. Jacinto AF, Brucki SMD, Porto CS, Martins MA, Nitrini R. Screening of cognitive impairment by general internists using two simple instruments. Dement Neuropsychol. 2012; 6(1):42-7.

37. Aguiar ACPO, Ribeiro MI, Jacinto AF. Subjective memory complaints in the elderly may be related to factors other than cognitive deficit. Dement Neuropsychol. 2010; 4(1):54-7.

38. Hohman TJ, Beason-Held LL, Lamar M, Resnick SM. Subjective cognitive complaints and longitudinal changes in memory and brain function. Neuropsychology. 2011; 25(1):125-30.

39. Li S, Okonkwo O, Albert M, Wang MC. Variation in variables that predict progression from MCI to AD dementia over duration of follow-up. Am J Alzheimers Dis (Columbia). 2013; 2(1):12-28.

40. Cooper C, Li R, Lyketsos C, Livingston G. Treatment for mild cognitive impairment: systematic review. Br J Psychiatry. 2013; 203(3):255-64.

41. Chertkow H. Mild cognitive impairment. Curr Opin Neurol. 2002; 15(4):401-7.

42. Petersen RC, Thomas RG, Grundman M, Bennett D, Doody R, Ferris S, et al.; Alzheimer's Disease Cooperative Study Group. Vitamin E and donepezil for the treatment of mild cognitive impairment. N Engl J Med. 2005; 352(23):2379-88.

43. Shinohara M, Yamada M. [Vitamin E and Alzheimer's disease]. Brain Nerve. 2015; 67(12):1509-13 